\title{
Euroopan koulutusjärjestämässä tulisi panostaa tieto- ja viestintäteknologiaan
}

\author{
European Round Table of Industria- \\ lists (ERT) on 45 eurooppalaisen \\ suuryrityksen pääjohtajien muodosta- \\ ma elin. Sen puheenjohtaja tällä \\ hetkellä on Nestlén pääjohtaja Helmut \\ Maucher. Suomesta Round Tableen \\ ovat kuuluneet Nokia ja UPM-Kymme- \\ ne. Kaksi vuotta sitten European \\ Round Table julkaisi yhteisen selvi- \\ tykseen perustuvan kannanoton \\ "Education for Europeans, Towards \\ the Learning Society". Nyt se on \\ saanut jatkoa. Toukokuun lopussa \\ ERT julkisti uuden asiakirjan "Inves- \\ ting in Knowledge, The Integration of \\ Technology in European Education. \\ Raporttia työstäneessä \\ työryhmässä toimi \\ myös osastopäällikkö \\ Kaisa Kautto-Koivula Nokia \\ Telecommunicationsista.
}

Asiakirja "Investing in Knowledge" painottaa uuden tieto- ja viestintäteknologian soveltamisen tärkeyttä koko koulutuksen prosessiin alaluokilta aikuisuuteen. Asiakirja on sävyltään ylevä, mutta se myös konkretisoi sanomaansa esittelemällä lyhyesti muutamia mielenkiintoisia uuden teknologian sovellutuksia oppimisen eri tasoilta. Asiakirjassa katsotaan uuden teknologian yleistymisen luovan edellytykset entistä tiiviimmän vuorovaikutuksen aikaansaamiseen työelämän ja koulumaailman välille. Vaikka raportin mukaan uusien tieto- ja viestintäteknologian välineiden käyttö avartaa koulutuksen ulottuvuuksia, yhteydet tiedon valtaväylille ovat kuitenkin vasta ensimmäinen askel kohti toimivaa tietoyhteiskunnan infrastuk-

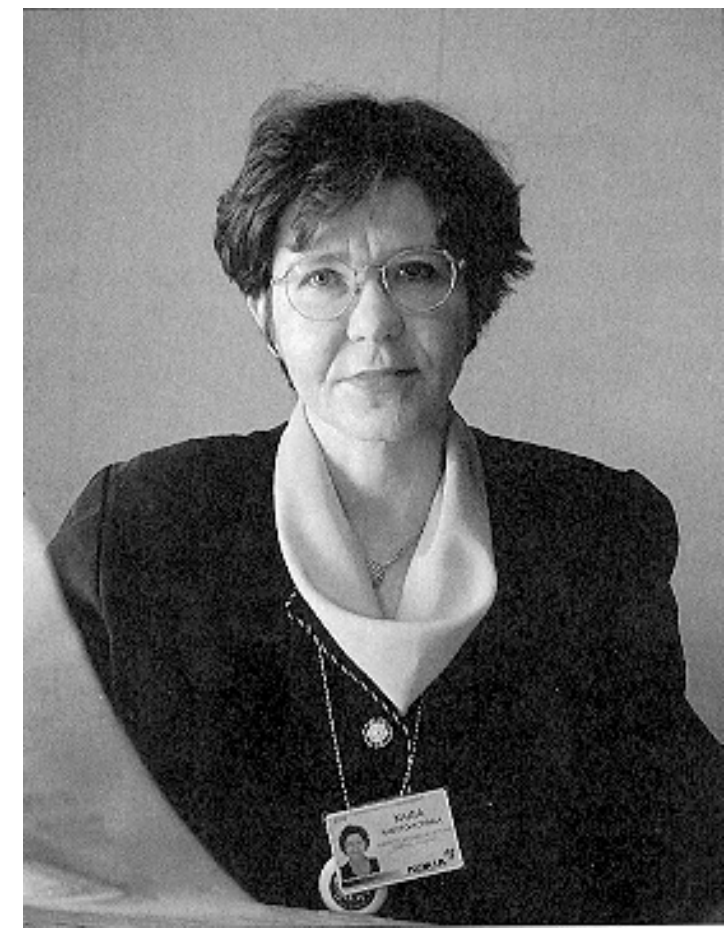

Ka isa Kautto-Koivula

tuuria kouluissa. Tutkimuksen mukaan tietoja viestintäteknologian tarjoamat mahdollisuudet voidaan hyödyntää laajemmin vasta, kun ne kyetään nivomaan tiiviisti osaksi normaalia opetus- ja oppimisprosessia läpi koko koulutusprosessin esikoulusta peruskouluun, ammatilliseen koulutukseen, yliopistoon ja työelämän aikuiskoulutukseen saakka.

Asiakirjojen takana on iso joukko eurooppalaisia suuryrityksiä ja heidän johtajiaan. Miten tiiviisti yritysten ylin johto on ollut mukana ohjelmajulistuksen teossa ja sitoutunut siihen? Miten tällaiset asiakirjat syntyivät käytännössä, Kaisa Kautto-Koivula? 
"The European Round Table of Industrialists toimii siten, että eri aihealueille on nimetty työryhmät ja kunkin sellaisen vetäjänä on Round Tablen jäsen, siis jonkun suurfirman pääjohtaja tai toimitusjohtaja. Koulutuksen työryhmä on niistä pitkäaikaisimpia ja sen vetäjänä on ollut mm. Kari Kairamo, joten suomalaisilla on ollut alusta lähtien varsin vankka panos. Nykyinen koulutustyöryhmän puheenjohtaja on Petroferonin pääjohtaja Francois Cornelis.

Mukana on nyt yli 40 eurooppalaista yritystä ja jokainen niistä on oikeutettu ilmoittamaan asiantuntijajäsenen kuhunkin työryhmään. Normaalitilanne on kuitenkin se, että työryhmissä työskentelee 15-20 hengen ydinjoukko. Koulutustyöryhmässä ovat yleensä olleet jäseninä firmojen henkilöstö- tai koulutusjohtajia tai muita asiantuntijoita. Työryhmät tekevät esityksiä tavoitteiksi, toimenpiteiksi ja tutkimusalueiksi ja Round Table vetää suuret linjat eli päättää yhteisistä tavoitteista, kuten siitä, mihin tutkimusta suunnataan. Yrityksethän maksavat tutkimuskulut. Kun Round Table on valinnut tutkimusten painopistealueet, asiantuntijoista koostuva ohjausryhmä täsmentää aihealueet ja päättää siitä, kenellä tai millä yliopistolla tai laitoksella tutkimukset teetätetään. Ohjausryhmä ohjaa tutkimustyötä, jotta teolli- suuden kannalta merkittävät asiat otetaan tutkimuksissa huomioon. Ohjaaminen tarkoittaa käytännössä sitä, että työryhmä määrittelee tutkimuksen tavoitteet ja miettii yhdessä tutkijaryhmän kanssa tutkimuksen rajauksen ja metodit. Tulokset otetaan sitten tuloksina eikä niitä kyseenalaisteta. Valmistunut tutkimus toimitetaan asiantuntijoiden tietoon ja päättäjille kootaan suppea raportti. Tässä selvityksessä ERT:n yhteistyökumppanina on ollut Leuvenin yliopisto Belgiassa."

\section{Asiakirja "Education for Europeans" Ioi pohjan}

Raportissa "Education for Europeans, Toward the Learning Society“ (1995) oli ydinkysymys se, vastaako Euroopan koulutus teollisuuden tarpeita. Yhtenä puutteena nähtiin teknologian heikko hyödyntäminen koulutuksessa.

"Round Tablella on hyvin yhtenäinen näkemys siitä, missä ovat koulutuksen karikot. Mutta asiat ovat vaikeita, sillä ollaan uuden ja monimutkaisen ajattelun edessä. Kysymys ei ole vain teknologiasta, vaan paljon muusta“, sanoo Kaisa Kautto-Koivula ja havainnollistaa kysymyksen näin:

\section{YMPÄRISTÖN MUUTOSPAINEET}

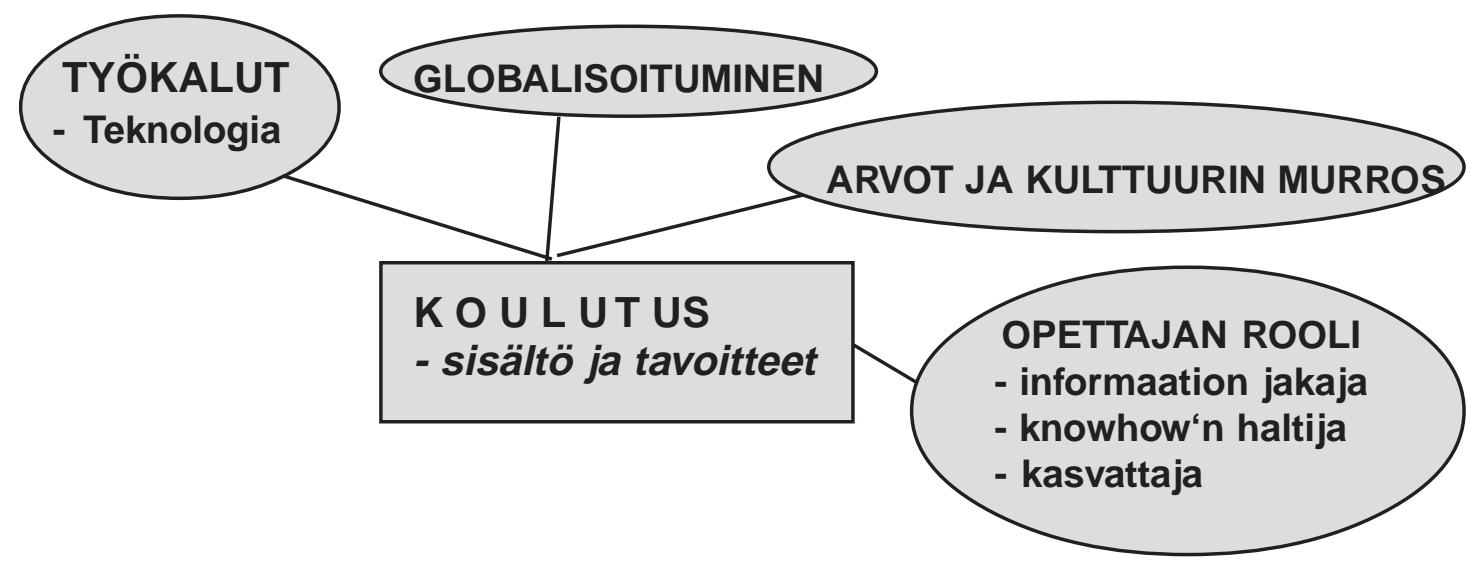

“Ensimmä inen ra porttitotesi,että koulutuseivastaa enää teollisuuden vaa timuksia. Ђiisin sa noen todettiin,että hyvin monetulko isetpa ineetkohdistuvat nytkoulutukseen",tïvistää Ka isa Kautto-Koivula. 


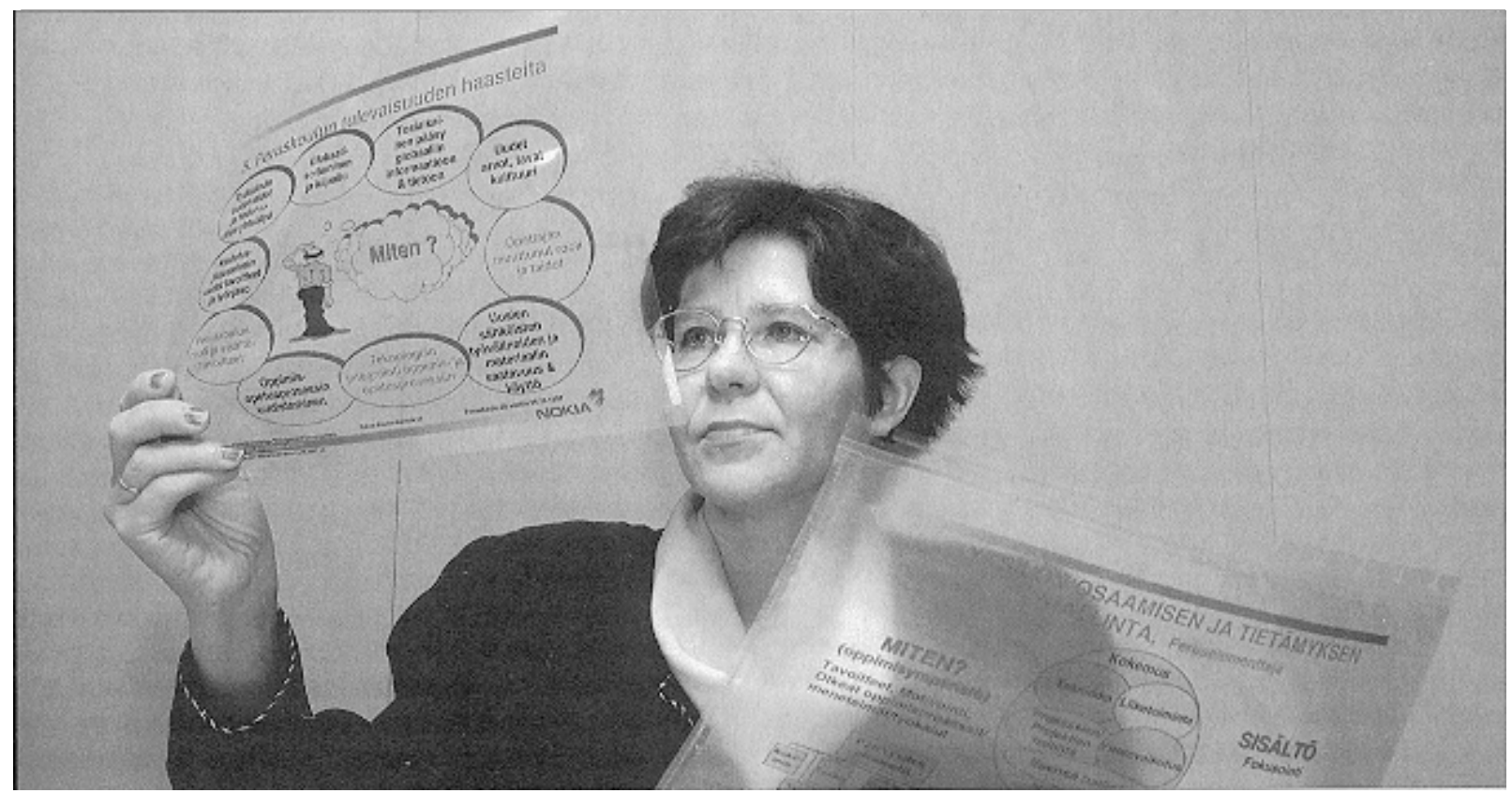

Kaisa Kautto-Koivula:

"Koulutukseen kohdistuu siis monia muutospaineita. Koulutusta ei kuitenkaan voida kehittää irrallisesti kunkin eri muutosvoiman osalta. Siksi ainoa tapa on nähdä eri vaikutustekijöiden aiheuttamat muutokset yhdessä ja miettiä kokonaisuus uudelleen: Miten koulutuksen pitäisi vastata muutokseen?

Koulutuksen sisällä se johtaa prosessin kehittämiseen. Se, että koulutuksen antaja (opettaja, koulutuslaitos) oli ennen informaationjakaja ja yliopistot olivat tietämyksen haltijoita, ei onnistukaan enää, vaan on mietittävä koko koulutusta prosessina lähtien lapsuudesta ja koulun alimmalta luokalta. On mietittävä, millaisia ihmisiä koulutusprosessista halutaan ulos, jotta he saisivat aikuisina töitä, ja missä osassa koulutuksen ketjua pitäisi tarjota mitäkin.

Enää ei arvosteta yksinomaan erillisten tietojen maksimointia, sillä tiedot vanhenevat nopeasti. Sen sijaan nyt arvostetaan myös sosiaalisuutta ja kommunikaatiotaitoja. Ne ovat aivan oleellisia. Sosiaalisten taitojen kehittymisen tärkeys täytyy ymmärtää siis jo ala-asteella. Niitä on vaikeampaa oppia myöhemmin, sillä myöhemmin olemassaolevissa perustaidoissa erikoistutaan. On tärkeää miettiä, miten koulutusprosessin eri vaiheissa saadaan näitä ihmisen tarvitsemia taitoja aikaiseksi, millä menetelmillä."

\section{Yksin ei enää selvitä}

"Sisältöjen muutoksen lisäksi koulutuksessa tarvitaan nyt käyttöön uusia sähköisiä työvälineitä, jotka tukevat yhteistyötä. Yksin ei enää selvitä, tarvitaan yhteistyötä. Miten se saadaan aikaan ja millä rahalla? Se on paljolti metodikysymys. Mahdollisuuksia on paljon. Mutta toteutuksessa tarvitaan yhteinen visio, jotta kaikki hoitaisivat oman leiviskänsä.

Tässä muutoksen myllerryksessä on suuri vaara, että opettaja kriisiytyy. Hänelle voi tulla sellainen tunne, ettei opettajaa enää tarvita, koska nähdään vain opettajan vanhat roolit eikä sitä, mitä opettajan roolin oikeasti pitäisi olla ja että juuri se uusi opettajan rooli on valtavan tärkeä. Asenteiden muutos koskee mitä suurimmassa määrin juuri opettajia. Miten saadaan opettajat innostumaan, miten saada heihin tun- 
ne, että olen 'supertärkeä' ja minun ei tarvitse junnata vanhassa roolissa? Koulutus menee verkostoyhteiskuntaan, halusi sitä tai ei. Mutta koulutus on valtavan suuri koneisto, eikä sen muuttaminen voi tapahtua nopeasti. Opettajankoulutus on kuitenkin aivan keskeinen kysymys.

Onnistuakseen tässä muutoksessa pitää pystyä näkemään, mikä nykyisessä opetuksessa on hyvää ja mikä huonoa. Huonoa on passiivinen kuuntelu ja se, että kateederin takana on Hän, joka tietää kaiken. Se oli teollisuusyhteiskunnan metodi. Se perustuu koululaitosajatteluun, eikä se toimi nyky-yhteiskunnassa. Verkostoyhteiskunnassa yksilön on oltava aktiivinen ja omavastuinen. Jos siis koulu eroaa liian paljon työelämän metodeista, elämä itsessään on shokki, kun sen kohtaa koulun jälkeen. Tarvitsemme elämässä selviämistaitoja, sillä taidot karttuvat, mutta tiedot vanhenevat."

Kaisa Kautto-Koivulan mielestä meillä mitataan nyt vääriä asioita. Mitataan yksittäisten tietojen määrää, kun pitäisi mitata ennemminkin taitoja. Siinä mittauksessa tarvitaankin aivan toisenlaisia mittareita ja välineitä.

"Se on globaali ongelma. Onneksi Suomi on kuitenkin kehityksessä kärkipäässä.“

\section{Miten tämä kaikki liittyy tieto- ja kommunikaatioteknologiaan?}

"Siten, että sähköiset työkalut auttavat meitä informaation lähteille ja sähköisten työkalujen avulla voimme kommunikoida toisella tavalla ja -laajuudessa kuin ennen. Kysymys on mm. siitä, että yhteistyön avulla osaaminen otetaan myös muiden käyttöön.

Sitä, mitä meillä on korvien välissä etenkin taitojen ja kokemusperäisen tietämyksen muodossa, ei voida läheskään aina opettaa. Toinen voi kuitenkin oppia sitä havainnoimalla, kuuntelemalla, oppipojan roolissa ja matkimalla eli olemalla läsnä, ei kielen tai kuvallisen ilmaisun kautta. Taitoja opitaan tekemällä tai/ ja ottamalla mallia. Sitä juuri on 'kasvatus'. Oppiminen vaatii siis läsnäoloa. Luokkaopetuksessa se on "siivellä oppimista", sillä "tuntumassa" opitaan paljon. Kaikki tällainen eliminoituu pois, jos työskentelee vain yksin näyttöpäätteellä.

Jotta ihminen pystyy kasvattamaan itsessään taitoja, hän tarvitsee harjoitusta: kommunikaatiotaitoja, taitoa toimia kasvotusten (vetämään aikuisena projekteja, pitämään esitelmiä, hoitamaan asioita). Koulumaailma ei siksi saisi olla keinotekoinen, vaan sen tulisi muistuttaa todellisuutta. Projektioppiminen on tässä hyvä keino. Metodit, joilla taitoja hankitaan, ovat vielä kuitenkin kalliimpia ja haastavampia kuin information jakamisessa tarvittavat metodit.

Seuraava kysymys on, mitä työvälineitä tietojen ja taitojen kartuttamisessa tarvitaan ja edelleen, miten ne rahoitetaan. Tekniikka voi tukea tehokkaasti globaalia informaationhankintaa ja kommunikointia etäällä olevien henkilöiden kanssa. Tekniikka voi olla taloudellisempi tapa myös tiedon ja taidon kartuttamiseksi, jos opettajan resurssit saadaan irrotettua ohjaukseen, kasvattamiseen ja itseluottamuksen vahvistamiseen. Se vaatii kuitenkin melkoisen myllerryksen aiemmassa ajattelussa ja tyssää aluksi kaikenlaisiin selityksiin ("ei ole aikaa", "ei ole rahaa“). On kysyttävä, olemmeko me fiksautuneet esteisiimme.

Eräs yritysjohtaja onkin todennut, että peruskoulun opettajan käsissä on lasten tulevaisuus. Se johtaa opettajan työn uuteen arvostukseen, sillä opettajan ammattitaidosta on kiinni, saadaanko aikaan oikeanlaisia asenteita, taitoja ja suhtautumista. Viisaita ovatkin ne maat, jotka tajuavat peruskoulun avainaseman, sillä yksilöiden itsensä hallintataidot ja kommunikointitaidot jakavat ihmiset nykypäivänä.“

Uusien työvälineiden rahoitus on suuri investointi ja siksi on aiheellista kysyä, pitäisikö yhteiskunnan ja yritysten jollain tapaa lyöttäytyä yhteistyöhön. Vielä yhteistyö ei ole kehittynyt luontevaksi ja helpoksi, vaan jokainen maa joutuu miettimään ratkaisunsa itse. Suuri kysymys on esimerkiksi koulujen eriarvoisuus työvälineissä: onko laitteita ja millaisia. Miten saa- 
daan riittävästi tarjontaa multimediaan perustuvan koulutusmateriaalin osalta?

Olemme suuressa murroksessa ja kukaan ei vielä tiedä, miten murrosta hallitaan. On kuitenkin erittäin tärkeää, että kaikki mukana olevat mieltävät murroksen samansuuntaisesti.

\section{Kokemusperäinen tieto nousee tärkeäksi}

Yliopistot, siis higher education, on myös murroksen edessä. Näin sen näkee Kaisa KauttoKoivula:

"On hyvin todennäköistä - ja monien yliopistojen johtajat on siitä myös tuskallisen tietoisia - että entiset kuuluisat, johtavat yliopistot saattavat tippua kärjestä, koska ne eivät halua tai pysty vastaamaan ympäristön muutospaineisiin riittävän nopeasti. Niiltä voi tippua vuosisatojen knowledge-valtikka, koska sähköisten tieto- ja viestintävälineiden ansiosta kuka tahansa pääsee helposti huipputiedon lähteille. Vastakkain joutuvat myös perinteinen ’korkein knowledge`, siis se, jota pelkistetään teorioiksi ja yleispäteväksi totuudellisuudeksi, ja se knowledge, joka on kasvanut ihmisten osaamisen ja kokemisen kautta ja jota tutkimus ei pysty tai ennätä jäljittämään. Sen tiedon ehdotonta totuudellisuutta ei ehditä enää testata, sillä siihen ei ole aikaa. Knowledge, joka saadaan tutkimuksen kautta, ja kokemuksellisen oppimisen kautta tuleva tiedontulva ovat vastakkain. Kumpi perii voiton ja kumpi ohjaa tulevaisuudessa kumpaa? Käytäntöpohjaista knowledgea on tähän asti katsottu hieman karsaasti tutkimusmaailmassa. Mutta nykyaikana tarvitaankin pelkistetyn teoreettisen tiedon sijasta yhä enemmän laaja-alaista tietoa, poikkitieteellistä knowledgea."

\section{ICT työkaluna}

Kaisa Kautto-Koivula:

"Jos ajattelemme ICT:tä (Information ja Communication Technology) ja oppimista, sitä tulee tarkastella eri tasoilla ja kullakin tasolla on omat ongelmansa.
MIKRO

Yksikön oppimisprosessi

- Millainen opetus- ja oppimisympäristö palvelee sitä?

MESO

$$
\begin{aligned}
& \text { Oppilaitos (= organisoidut opetus- } \\
& \text { ympäristöt) } \\
& \text { - Millaiset opetussisällöt, -ohjel- } \\
& \text { mat ja -menetelmät ovat ihanteel- } \\
& \text { lisimmat? }
\end{aligned}
$$

\section{MAKRO Lähiympäristön, yhteiskunnan ja} yhteiskuntien taso

- oppilaitokset linkittyvät ympäristöönsä paikallisesti

- kansallinen taso

- Euroopan taso

- globaali taso

Miten nämä toimivat ja mitkä ovat niiden vastuualueet tulevaisuudessa.

Tulee siis pohtia, mitä ongelmia voidaan ratkaista milläkin tasolla. Kaikilla tasoilla on nähtävä muidenkin tasojen merkitys. Joudutaan pohtimaan, mikä on oppilaitoksen rooli tulevaisuudessa. Mikä on niiden uusi merkitys organisoitujen oppimisympäristöjen kehittämisessä?

Jos ajattelemme PKT-yrityksiä ja suuryrityksiä Euroopassa sekä yritysten eri johtotasoja, missä ovat suurimmat asenteelliset valmiudet koulutusinvestointeihin ja koulutusteknologiainvestointeihin ja missä ovat suurimmat heikkoudet?

"Yritysmaailman sisällä on todella pitkä skaala PKT-sektorilta suuryrityksiin, jotka ovat jonkinlaisia muutoksen indikaattoreita. Työttömien joukossa on paljon sellaisia, joilla ei ole taitoja, ja vastaavasti työssä käyvissä on paljon sellaisia, jotka ovat saaneet koulutuksensa johonkin muuhun ammattiin ja jotka ovat hankkineet taitoja muunsisältöiseen työhön. Kysymys on siis enemmän taitojen hallinnasta ja kyvystä muunnella niitä.

European Round Tablessa on mukana yrityksiä ja koulutuslaitoksia, jotka toimivat indikaattoreina siinä, missä on muutoksen paineita ja esteitä.“ 


\section{Teknologia ei ole ongelmatonta, mutta välttämätön se on}

Suomessa kouluviranomaiset ajattelevat ja toimivat samansuuntaisesti kuin ERT:n piirissä on tiedostettu. Niinpä vuonna 2000 on kaikkien Suomen koulujen määrä olla internetissä. Tekniikka kehittyy kaiken aikaa. Kysymys on kustannuksista: miten saadaan riittävä tekniikka kouluihin kohtuuhinnalla. Ja jos välineet saadaankin kohtuuhinnalla, se ei vielä kerro sitä, osataanko niitä käyttää. Ongelmia on lisäksi tekniikan päivitys.

Ei internet ole ainoa mahdollisuus. Esimerkiksi TV on loistava ja edullinen väline, ja etenkin, jos sitä kehitetään interaktiiviseksi, mihin digitaalisuus antaa hyvät mahdollisuudet."

Seppo Tella toteaa artikkelissaan Aikuiskasvatuksen tässä numerossa verkoissa olevien asiantuntijoiden olevan poikkeuksellisen altruistisia jakaessaan tietämystään muiden verkossa olevien kesken. Mutta hän näkee myös merkkejä siitä, että verkkoepäitsekkyys on vähenemässä ja asiantuntijuudesta tulee yhä enemmän kauppatavaraa. Eikä tämä ole uusi suuri ongelma ajatellen kouluja ja niiden tasa-arvoisuutta?

“Minäkin pidän mahdollisena ja todennäköisenäkin, että ekspertiys jakautuu. Jotkut tekevät sillä kauppaa, jotkut käyttävät sitä knowledgen vaihtoon ja jotkut toimivat edelleen altruistisesti. Yksi kehitysvaihtoehto voisi olla oppilaitosten keskinäinen työnjako eli kunnon vanha oravannahkojen vaihto. Voi käydä myös niin, että yksi erikoistuu yhteen osaamiseen, myy sen internetissä ja saa vuorostaan rahaa ostaa muiden osaamista. Kummassakin tapauksessa tarvitaan asenteiden muuttumista ja mielikuvitusta.“

"Investing in Knowledge" -raportissa puhutaan useissa kohdin Euroopan yhteishyvästä ja Euroopan tulevaisuudesta. Kun mukana olevista 45 suuryrityksestä osa on keskenään toistensa pahimpia kilpailijoita ja jokainen yritys vannoo globaalisuuden nimiin, miksi Eurooppa yhdistää niitä? Tarvitaanko uusi "kotimaan" käsite, kun kansallisten valtioiden merkitys on liuennut ohueksi?

"Hyvä kysymys. European Round Tablessa mukana olevilla suurfirmoilla - niin globaaleja kuin ne ovatkin - sijaitsevat keskeisimmät toimintapisteet kuitenkin vielä Euroopassa. Silloin on tärkeää, että niiden toimintaympäristö on kehittynyt ja että niiden toimintaympäristössä väki on suhteellisen osaavaa ja koulutettua. Kyse ei ole saarekeajattelusta Eurooppa vastaan muu maailma. On toivottavaa, että Eurooppa yhdistyy niiden maiden kanssa, jotka ovat sitä lähellä.

On myös kyse siitä, että isossa murroksessa kuten koulutusjärjestelmiä koskevissa - yksikään yritys ei pysty yksin muuttamaan koulutuksen suuntaa ratkaisevasti, vaan isoja kysymyksiä on käsiteltävä yhdessä. On järkevää pohtia yhdessä sitä, mitä asioita on hyödyllistä tehdä milläkin tasolla ja mitä asioita yritetään tehdä yhdessä koko Euroopan tasolla“, sanoo osastopäällikkö Kaisa Kautto-Koivula Nokia Telecommunicationsista.

USÄTIETOJ A

The European Round Table of Industria lists

B-1060 Brussels

Tel: 32 2/534 31 00, fax 32 2/534 7348

email: ert@skynet.be

http://www.ertbe

European Round rableen kuuluvatyritykset vuoden 1997 lopun tila nteen mukaan:

ABB,Airbus Ind ustry,Amorim G roup, B.A.TInd ustries, Bayer,Bertelsmann,BPBT, C a rlsberg, Da imlerBenz, Eric sson, Fiat, Fried. Krupp, G eva ert, G KN,Hoffma nnLa Roc he,Iberdrola ,IC I, J efferson Smurfit,Lafarge, Lyonna ise desEa ux, Ma rzotto, Nestlé,Nokia, Norsk Hydro,O livetti,OMV,PetroFina m, Philips,Pilkington, Pirelli,Profilo Hold ing, Rena ult,Repsol,Rhone-Poulenc, RobertBosch,RoyalDutch/Shell,Sa int-Gobain, Siemens, Solva y, Sta toil,Sté Gén.de Belgique,Titan Cement,Unilever,Veba.

Ka isa Kautto-Koivula työskentelee nykyisin entyisasiantuntijana Sitrassa (ks. sivu 349).

Haastattelu: ANNELI KAJANTO

Kuvat: KALEVI KESKI-KORHONEN 